this step does not lie with the educational centres, but with the private owners themselves. As has been advocated for a number of years now, if a few adjacent private owners of forest land would join together, they could easily afford to pay for the services of a man who has taken full training in forestry and done well at his examinations. In any event, wherever a man goes, to whatever Government service, he will have to learn the ropes during his first year or more before he can become fully efficient in carrying out the work of the department in question. This holds equally good for the young fully trained man appointed to private forestry; but the bogy that they will be carrying a 'dud' for three to five years is entirely without reason : and to sit and wait, as some owners of private estates have been doing for the last forty years in some cases, until they can pick up a fully trained man with full experience-obtained, it may be well asked, from where?-is not, it may be suggested, the way in which Mr. Ackers' aspirations will be fulfilled. That such trained men are fully as necessary to the management of large areas of private forests as to the large areas under the Forestry Commission is so obvious that it does not need discussion.

In the chapter on the nursery the following topies are dealt with : temporary nurseries; choice of a nursery site; shelter; cleanliness; soils, of course, and then seed and its extraction; period of sowing; depths of sowing and covering, and sowing distances ; the collection of seed, and the dangers to which both seed and young plants are subject from birds, mice, moles, damping off and frost; the size of the plants to be put out in the forest; transplanting in the nursery from the seed beds; use of manures and rotation of areas in the nursery ; season of planting; transport troubles and the use of sets and cuttings; packing and unpacking, and heeling the plants on arrival at their new position, previous to planting them out.

As in the former edition, the present one contains a number of good illustrations. The author may be congratulated on his presentation of the subject.

E. P. Stebbing

\section{EARTHQUAKES AND VOLCANOES}

\section{Séismes et Volcans}

Par Prof. J.-P. Rothé. (Que sais-je ?, No. 217.) Pp. 136. (Paris: Presses universitaires de France, 1946.)

$\mathrm{T}$ WHS small book, with approximately the size and format of a British Penguin book, is believed to be the first written by Prof. J.-P. Rothé, of Strasbourg, the seismologist and son of the late Prof. E. Rothé, the distinguished French geophysicist. It is a worthy beginning. The book is accurate though semi-popular.

The five chapters concern the study of the visible effects of severe earthquakes, instrumental seismology and an earth model, earthquake geography, the supposed causes of earthquakes, and there is one chapter on volcanoes. The selection of material for the book has evidently been carried out with considerable care. Three earthquakes especially mentioned are the Provence earthquake of June 11, 1909, the Chilian earthquake of January 25, 1939, and the Roumanian earthquake of November 10, 1940. In a book of this sort it is a definite benefit to have large earthquakes mentioned which have occurred recently, even though there have been greater ones well described in such books as those by Dr. Charles Davison. The Chilian earthquake was undoubtedly one of the greatest earthquakes of the world and was so figured in Nature at the time. The macro. seismic study of earthquakes still demands attention, for although it may be possible for an earthquake to start in a volume approaching a point, yet the mechanics of plane faulting figure largely both in the immediate cause and effect of earthquakes. Hidden faults have been mapped by instrumentally determined earthquake foci.

The chapter on seismic waves states clearly the elementary ideas underlying earthquake-recording instruments and the records obtained from these, and points out named waves on the records. The paths of these waves are shown on an earth model. There are no mathematics in the chapter, and seismic prospecting is confined to two pages. Seismologists and seismic prospectors will look forward to the promised book by the Rothés which is now being prepared.

The general outline of earthquake geography including deep-focus earthquakes as proved by Scrase is well described, and the regional earthquake geography of two well-explored regions, California by numerous American seismologists and the European Alps by J.-P. Rothé, is ably summarized. I myself feel that more modern attention to such subjects as are dealt with in "La Géologie Séismologique" by Montessus de Ballore would amply repay the time spent.

The 'causes' of earthquakes is a thorny subject, especially where it links up with isostatic theory. Epeirogenic and orogenic movements are considered and emphasis is placed on structure. The convection hypothesis, which incidentally assumes finite viscosity at moderate depths in the earth, is dealt with in conjunction with the gravity axis of Vening Meinesz near the Dutch East Indies. The theory of Wegener concerning moving continents is also mentioned.

Any theory of the origin of earthquakes must be capable of explaining the known facts of earthquake geography, such as the circum-Pacific belt and the South European-Asiatic belt, together with the limited distribution of deep-focus earthquakes and the gradual deepening of foci as we go from Spain via the Pamirs to Java. Seismology as an independent science is still young and has made great strides during the past forty years. That there are more problems to answer is a spur to those working on the subject. That the science is growing quickly is seen by the fact that the latest use of microseismic move. ment as a storm-centre locator at sea, and thus the use of the seismograph as a meteorological instrument, is not mentioned in Rothé's book.

Volcanoes are associated with earthquakes in the minds of people probably because both are catastrophic and unpredictable, and because both often occur in the same countries. Apart from both being associated with 'young' mountains, they have little else in common. This is made clear in a very concise terminal chapter in this admirable little book.

The books in this series "Que sais-je?", published by the Presses universitaires de France, together form a popular modern encyclopædia on most branches of human thought. Sixty-eight volumes on pure science are mentioned on the cover. The general idea is commended to publishers of British Penguin and other low-priced books. ERnEST TILLOTSON 